\title{
Gestão de resíduos da arborização urbana Possibilidades e desafios para valorização
}

\author{
Ana Maria de Meira \\ Escola Superior de Agricultura Luiz de Queiroz / USP \\ Doutora em Ciências, ammeira@usp.br
}

\section{RESUMO}

O trabalho resulta de uma tese de doutorado desenvolvida no Departamento de Ciências Florestais da ESALQ/USP que apresenta modelos de quantificação, classificação e potencialidades de valorização de resíduos da arborização urbana, conforme a classe de diâmetro e ensaios laboratoriais para fins de produção de carvão, composto orgânico e produtos sólidos de madeira, reforçando a necessidade de planejamento das florestas urbanas para ampliar a prestação dos seus serviços ambientais.

Palavras-chave: modelo de quantificação, valorização de resíduos, arborização urbana, planejamento.

\section{ABSTRACT}

This work is the result of a doctoral thesis developed at the Department of Forest Sciences at the ESALQ/USP, which presents models for quantifying, classifying and potential for the valorization of waste from urban afforestation, according to the diameter class and laboratory tests for the purposes of coal production, organic compost and solid wood products, reinforcing the need for planning urban forests to expand the provision of their environmental services.

Keywords: quantification model, waste recovery, urban afforestation, planning. 